\title{
BIOLOGICAL ACTIVE LIFE OF PMSG IN MICE WITH SPECIAL REFERENCE TO FOLLICULAR ABILITY TO OVULATE
}

\author{
SHUJI SASAMOTO, KAHEI SATO* AND HIROYUKI NAITO $\dagger$ \\ Laboratory of Veterinary Physiology, Tokyo University of Agriculture and Technology, \\ Musashi-Fuchu, Tokyo 183, Japan
}

(Received 16th July 1971, accepted 6th December 1971)

\begin{abstract}
Summary. Experiments were designed to determine whether PMSG is essential for the continued maturation of follicles whose initial development is stimulated by the hormone in immature mice. Anti-PMsg serum (APs), prepared in rabbits, was used at various times after pretreatment with PMSG to determine the time required for PMSG to mature follicles. Follicular maturity was tested by the ovulatory response to HCG.

When HCG was given 54 to $60 \mathrm{hr}$ after PMSG, maximum ovulation was obtained. When APS was given $54 \mathrm{hr}$, followed by HCG $60 \mathrm{hr}$, after PMSG, the percentage ovulation rate decreased significantly from that of the corresponding control group in which APS and HCG were given simultaneously $54 \mathrm{hr}$ after PMSG. When HCG was given $72 \mathrm{hr}$ after PMSG, ovulation did not occur regularly. When a small amount of supplementary PMSG was given $58 \mathrm{hr}$ after the initial dose, ovulation was induced regularly by HCG $72 \mathrm{hr}$ after pretreatment with PMSG.

From these experiments, it is concluded that a small amount of PMSG remains in the circulating blood up to 54 to $60 \mathrm{hr}$ after the pretreatment with PMSG in immature mice. Blood levels of PMSG decrease below the threshold for the maintenance of follicles $72 \mathrm{hr}$ after pretreatment.
\end{abstract}

\section{INTRODUCTION}

Ovulation is readily induced in immature mice and rats by the consecutive administration of PMSG and HCG. The optimum interval between PMSG and HCG is 54 to $56 \mathrm{hr}$ (Rowlands, 1944; Runner \& Palm, 1953; Zarrow, Caldwell, Hafez \& Pincus, 1958; Sasamoto \& Murakami, 1961b; Wilson \& Zarrow, 1962). When HCG administration is delayed until $72 \mathrm{hr}$ after pretreatment with $2 \cdot 5$ i.u. PMSG, ovulation in immature mice does not occur regularly, even with a large amount of HCG. Histologically, follicles appear to begin to degenerate $72 \mathrm{hr}$ after treatment with $2 \cdot 5$ i.u. PMSG (Imai, Sasamoto \& Suzuki, 1965).

The present paper is primarily concerned with the time at which PMSG must be present in the circulating blood for follicles to develop to the stage where they are capable of responding to ovulating hormones. Secondarily, the ques-

\footnotetext{
* Present address: Laboratory of Animal Reproduction, Nihon University, Setagayaku, Tokyo.

$\dagger$ Present address: Department of Veterinary Physiology, University of Tokyo, Bunkyoku, Tokyo.
} 
tion of whether such follicles can be maintained without circulating PMSG is examined, using the neutralizing action of anti-PMSG serum in immature mice pretreated with PMSG. The effect of supplementary administration with a small amount of PMSG on the maintenance of follicles up to $72 \mathrm{hr}$ is also examined.

\section{MATERIALS AND METHODS}

Immature female mice, aged 20 to 25 days and weighing 7.0 to $9.5 \mathrm{~g}$ at the beginning of the experiment, were obtained commercially and randomly allotted to the treatment groups.

An injection of 2300 i.u. PMSG $/ \mathrm{mg}$ was used to stimulate follicle growth and of 2200 i.u. HGG $/ \mathrm{mg}$ to induce ovulation. All injections were given in a total volume of $0.1 \mathrm{ml} 0.9 \% \mathrm{NaCl}$. The mice were killed with chloroform 20 to $24 \mathrm{hr}$ after the HGG injection to examine for the presence of tubal ova by the method of Burdick \& Whitney (1941). The percentage of mice ovulating was used as a measure of response throughout the experiments.

\section{Preparation of anti-PMSG serum and assay of its activity}

Two rabbits (No. 2 and No. 4), weighing 2.0 to $2.5 \mathrm{~kg}$, were used. Pregnant mares' serum gonadotrophin, $2300 \mathrm{i} . \mathrm{u} . / \mathrm{mg}$, was dissolved in $0.9 \% \mathrm{NaCl}$ to a concentration $1 \mathrm{mg} / \mathrm{ml}$. This solution was emulsified in an equal volume of Freund's complete adjuvant and $2 \mathrm{ml}$ of the mixture was injected intramuscularly once a week for 15 weeks. A booster injection of $1 \mathrm{mg}$ PMSG in $1 \mathrm{ml} 0.9 \%$ $\mathrm{NaCl}$ was made intravenously 7 days after the last intramuscular injection.

The rabbits were bled by heart puncture 15 days after the booster injection. The anti-PMSG serum (APs) from each rabbit was diluted tenfold with $0.9 \%$ $\mathrm{NaCl}$, and stored in small aliquots at $-20^{\circ} \mathrm{C}$. It was thawed just before use and any unused portions were discarded.

The activity of APs was determined by its ability to inhibit the ovulating capacity of PMSG. The test was carried out in immature mice pretreated with $2 \cdot 5$ i.u. PMSG. Fifty-four to $56 \mathrm{hr}$ after the pretreatment with PMSG, the animals were injected subcutaneously with 3 i.u. PMSG to induce maximum ovulation. Serial dilutions of APs in $0.9 \% \mathrm{NaCl}$ were prepared and injected simultaneously with the ovulating dose of PMSG into a different subcutaneous site in each mouse in a standard volume of $0.1 \mathrm{ml}$. One unit of APS was defined as the amount capable of inhibiting 1 i.u. PMsG.

The activity of APS was also checked by its ability to inhibit the ovarian and uterine weight-increasing capacity of PMSG. Immature mice were injected with 3 i.u. PMSG and 3 units APS simultaneously at different subcutaneous sites. The animals were killed 54 to $56 \mathrm{hr}$ after the injections for the measurement of ovarian and uterine weights. The uteri were weighed after pressing out the uterine fluid on blotting paper.

\section{RESULTS}

The activity of anti-PMSG serum

The amount of APS required to inhibit the activity of PMSG was determined for 
each serum sample. A dose of 3 i.u. PMSG, known to elicit maximum ovulation (Sasamoto, 1962, 1969), was given with varying amounts of APs.

The results (Table 1 ) indicate that the activity of PMSG was inhibited in direct proportion to the amount of APS given. For complete inhibition, the amount of APS required from Rabbit No. 2 (APs-2) or from Rabbit No. 4 (APs-4) was $0.0002 \mathrm{ml}$. Thus, $1 \mathrm{ml}$ of APs-2 or APS- 4 was computed to contain 15,000 units.

TABLE 1

THE CAPAGITY OF ANTI-PMSG SERUM TO PREVENT PMSG-INDUGED OVULATION IN IMMATURE MICE PRETREATED WITH PMSG

\begin{tabular}{l|cccccc}
\hline & \multicolumn{6}{|c}{ Amount of APS in ml from Rabbit No. 2 (APS-2) } \\
\cline { 2 - 7 } & 0 & 0.000025 & 0.00005 & 0.0001 & 0.0002 & 0.0004 \\
\hline $\begin{array}{l}\text { Proportion of mice ovulating } \\
\text { Ovulation }(\%)\end{array}$ & $9 / 10$ & $6 / 8$ & $14 / 20$ & $5 / 19$ & $0 / 10$ & - \\
\hline
\end{tabular}

\begin{tabular}{l|ccccccc}
\hline & \multicolumn{7}{|c}{ Amount of APS in ml from Rabbit No. 4 (APS-4) } \\
\cline { 2 - 7 } & 0 & 0.000025 & 0.00005 & 0.0001 & 0.0002 & 0.0004 \\
\hline $\begin{array}{l}\text { Proportion of mice ovulating } \\
\text { Ovulation (\%) }\end{array}$ & $20 / 20$ & $10 / 10$ & $10 / 10$ & $9 / 20$ & $0 / 10$ & $0 / 10$ \\
\hline
\end{tabular}

APS = Anti-PMSG serum. All mice received 3 i.u. ovulatory PMSG and variable quantities of APS, 54 to $56 \mathrm{hr}$ after the pretreatment with $2 \cdot 5$ i.u. PMSG.

TABLE 2

OVARIAN AND UTERINE WEIGHTS OF THE IMMATURE MICE TREATED WITH SALINE, PMSG AND ANTI-PMSG SERUM, OR PMSG

\begin{tabular}{l|c|c|c}
\hline \multicolumn{1}{c|}{ Treatment } & No. of mice & $\begin{array}{c}\text { Ovarian weight }(\mathrm{mg}) \\
\text { Mean } \pm \text { S.E. }\end{array}$ & $\begin{array}{c}\text { Uterine weight }(\mathrm{mg}) \\
\text { Mean } \pm \text { S.E. }\end{array}$ \\
\hline Saline & 14 & $7 \cdot 29 \pm 0.54$ & $10.21 \pm 0.79$ \\
\hline $\begin{array}{l}3 \text { i.u. PMSG } \\
+3 \text { units APs* }\end{array}$ & 14 & $7.57 \pm 0.47$ & $11.64 \pm 0.75$ \\
\hline 3 i.u. PMSG & 18 & $11.83 \pm 0.64$ & $23.00 \pm 1.07$ \\
\hline
\end{tabular}

Animals were killed 54 to $56 \mathrm{hr}$ after the treatment.

* PMSG and anti-PMSg serum (APs) from Rabbit No. 4 were injected simultaneously in different subcutaneous sites.

Three units of APS- 4 were given simultaneously with 3 i.u. pretreatment PMSG to check the activity of APs by ovarian and uterine weight methods. The results (Table 2) indicate that no significant increases were observed in the ovarian or uterine weights of the APS- and PMSG-treated group as compared with those of the saline-treated group. The inhibition of the ovarian or uterine weight increase in the APS- and PMSG-treated group was highly significant as compared with that of the group treated with 3 i.u. PMSG. 


\section{Effect of time of administration of APS on HCG-induced ovulation}

Immature mice pretreated intravenously with 3 i.u. PMSG were given 6 units APs intravenously and an ovulating dose of 1 i.u. HCG subcutaneously. AntiPMSG serum and HCG were administered simultaneously at varying intervals after pretreatment with PMSG in order to determine the period during which PMSG must be present in the circulating blood for the follicles to develop to the stage where they are capable of ovulation. The results of this experiment are given in Table 3.

When APS and HCG were given $60 \mathrm{hr}$ after pretreatment with PMSG, maximum ovulation was obtained (Group I); no inhibitory effect of APS on the ovulating activity of HCG was observed for the level of APS used in this experiment. When APS and HCG were injected $54 \mathrm{hr}$ after PMSG, $94 \%$ of the mice ovulated with no significant difference from that of the maximum ovulation group (Group IV-a).

TABLE 3

EFFECT ON HCG-INDUCED OVULATION OF ANTI-PMSG SERUM GIVEN AT DIFFERENT TIMES AFTER PRETREATMENT WITH PMSG IN IMMATURE MIGE

\begin{tabular}{l|l|c|c|c}
\hline Group & \multicolumn{1}{|c|}{ Treatment } & $\begin{array}{c}\text { Proportion of mice } \\
\text { ovulating }\end{array}$ & $\%$ Ovulation & P \\
\hline I & PMSG $+60 \mathrm{hr}$ (APS + HCG) & $28 / 28$ & 100 & \\
\hline II-a & PMSG $+36 \mathrm{hr}$ (APS + HCG) & $8 / 18$ & 44 & $0.005^{*}$ \\
II-b & PMSG +36 hr APS +60 hr HCG & $0 / 27$ & 0 & $0.005 \dagger$ \\
\hline III-a & PMSG +48 hr (APS+HCG) & $31 / 38$ & 82 & $0.025^{*}$ \\
III-b & PMSG +48 hr APS +60 hr HCG & $11 / 27$ & 41 & $0.005 \dagger$ \\
\hline IV-a & PMSG +54 hr (APS+HCG) & $34 / 36$ & 94 & N.S.* \\
IV-b & PMSG +54 hr APS+60 hr HCG & $11 / 19$ & 58 & $0.005 \dagger$ \\
\hline
\end{tabular}

PMSG pretreatment ( 3 i.u.) and anti-PMSG serum (APS-6 units) were injected intravenously in the tail and HCG (1 i.u.) was given subcutaneously; all the mice were killed 20 to $24 \mathrm{hr}$ after HCG.

* Compared to Group I (N.S.-not significant).

$\uparrow$ Compared to the corresponding Group-a.

When APS and HCG were injected $48 \mathrm{hr}$ or $36 \mathrm{hr}$ after PMSG, the percentage ovulation rate was significantly decreased to 82 (Group III-a) or 44 (Group II-a), respectively. These results indicate that PMSG must be present for 54 to 60 $\mathrm{hr}$ in the circulating blood for the development of mouse follicles to the stage capable of maximum ovulation.

To examine whether the presence of PMSG is necessary in the circulating blood to maintain the follicles after they have developed the capacity to ovulate, groups of mice pretreated with 3 i.u. PMSG were all injected $60 \mathrm{hr}$ later with 1 i.u. HCG subcutaneously. Maximum ovulation normally occurs following HCG administration. A single intravenous injection of 6 units APs was made at varying intervals after the intravenous pretreatment with PMSG. The results of this experiment are also given in Table 3.

Whereas $94 \%$ ovulation was obtained by simultaneous injections of APS and HGG $54 \mathrm{hr}$ after PMsG (Group IV-a), the percentage of animals ovulating decreased significantly to 58 when HCG injection was delayed for $6 \mathrm{hr}$ following 
APS (Group IV-b). A similar decrease in percentage ovulation rate was also observed when APS was given $48 \mathrm{hr}$ after PMSG, followed by HCG $12 \mathrm{hr}$ later (Group III-b). When there was a 24-hr interval between APS and HCG injections, no ovulation was observed.

These results indicate that even if PMSG was continuously present in the circulating blood until $6 \mathrm{hr}$ before the ovulating HGG injection, the follicles could not be maintained in the state capable of maximal ovulation during the last $6 \mathrm{hr}$. Once the follicles had developed the capacity to ovulate, none could be maintained for $24 \mathrm{hr}$ without circulating PMSG. The presence of PMSG in the circulating blood was required for at least $54 \mathrm{hr}$ after the injection in order to develop and maintain the follicles.

\section{Effect of a small amount of supplementary $P M S G$ on $H C G$-induced ovulation}

The following experiment was undertaken in order to examine the effect of a small amount of supplementary PMSG on the maintenance of follicular ability to ovulate.

TABle 4

EFFEGT ON HGG-INDUCED OVULATION OF SUPPLEMENTARY PMSG IN IMMATURE MICE PRETREATED WITH PMSG

\begin{tabular}{|c|c|c|c|c|c|}
\hline \multirow{3}{*}{ Group } & \multirow{3}{*}{ Treatment } & \multicolumn{4}{|c|}{$\begin{array}{c}\text { No. of mice ovulating/no. of mice examined } \\
(\% \text { ovulation rate })\end{array}$} \\
\hline & & \multicolumn{4}{|c|}{ Amount of $H C G$ (i.u.) } \\
\hline & & 0.27 & 0.40 & 0.60 & 0.90 \\
\hline $\begin{array}{l}\mathrm{I}-\mathrm{a} \\
\mathrm{I}-\mathrm{b}\end{array}$ & $\begin{array}{l}\text { PMSG } 2.75 \text { i.u. }+54 \mathrm{hr} \text { HCG } \\
\text { PMSG } 2.75 \text { i.u. }+72 \mathrm{hr} \text { HCG }\end{array}$ & $\begin{array}{l}2 / 11(18) \\
1 / 11 \quad(9)\end{array}$ & $\begin{array}{l}6 / 12(50) \\
2 / 13(15)\end{array}$ & $\begin{array}{r}11 / 13(85) \\
6 / 12(50)\end{array}$ & $\begin{array}{r}12 / 12(100) \\
5 / 13(38)\end{array}$ \\
\hline $\begin{array}{l}\text { II-a } \\
\text { II-b }\end{array}$ & $\begin{array}{l}\text { PMSG } 2.5 \text { i.u. }+54 \mathrm{hr} \text { HCG } \\
+58 \mathrm{hr} \text { PMSG } 0 \cdot 25 \mathrm{i} . \mathrm{u} . \\
\text { PMSG } 2 \cdot 5 \text { i.u. }+58 \mathrm{hr} \text { PMSG } \\
0 \cdot 25 \text { i.u. }+72 \mathrm{hr} \text { HCG }\end{array}$ & $\begin{array}{l}3 / 14(21) \\
2 / 14(14)\end{array}$ & $\begin{array}{l}8 / 15(53) \\
4 / 16(25)\end{array}$ & $\begin{array}{l}15 / 17(88) \\
13 / 16(81)\end{array}$ & $\begin{array}{l}16 / 16(100) \\
13 / 15 \quad(87)\end{array}$ \\
\hline
\end{tabular}

All injections were made subcutaneously and animals were killed 20 to $24 \mathrm{hr}$ after HCG.

Two large groups were prepared. One group was injected with $0 \cdot 25$ i.u. supplementary PMSG $58 \mathrm{hr}$ after pretreatment with 2.5 i.u. PMSG. The other group was pretreated with 2.75 i.u. PMSG and received no supplementary PMSG. In both groups, the total amount of PMSG administered was $2 \cdot 75$ i.u. and all injections were made subcutaneously. Each group was divided into two subgroups, and received the HCG injection either 54 or $72 \mathrm{hr}$ after PMSG pretreatment. The details of the dose of HCG and the dose-response relationship obtained for the percentage of mice ovulating are given in Table 4.

When HGG was given $54 \mathrm{hr}$ after PMSG pretreatment, good dose-response relationships were obtained in both Group I-a and Group II-a. When the HCG injection was delayed until $72 \mathrm{hr}$ after PMSG pretreatment, the percentage of mice ovulating did not increase above 50 (Group I-b) without the supplementary PMSG, and no further statistical analysis was undertaken with the results from this sub-group. In the group given supplementary PMSG, however, 
the dose-dependent increase in percentage ovulation rate was observed even if HCG injection was delayed until $72 \mathrm{hr}$ after PMSG pretreatment (Group II-b) (Text-fig. 1).

The percentages of mice ovulating were transformed to probits against the doses of HCG on a log scale. The results were computed as a parallel line assay by the method of Finney (1964). In the following computations, the results with $0.27,0.4$ and $0.6 \mathrm{i}$.u. HCG were used. In the group injected with supplementary PMSG, no significant departure from linearity or parallelism was noted. The results gave a potency of 0.82 for the $72-\mathrm{hr}$ HGG injection relative to the

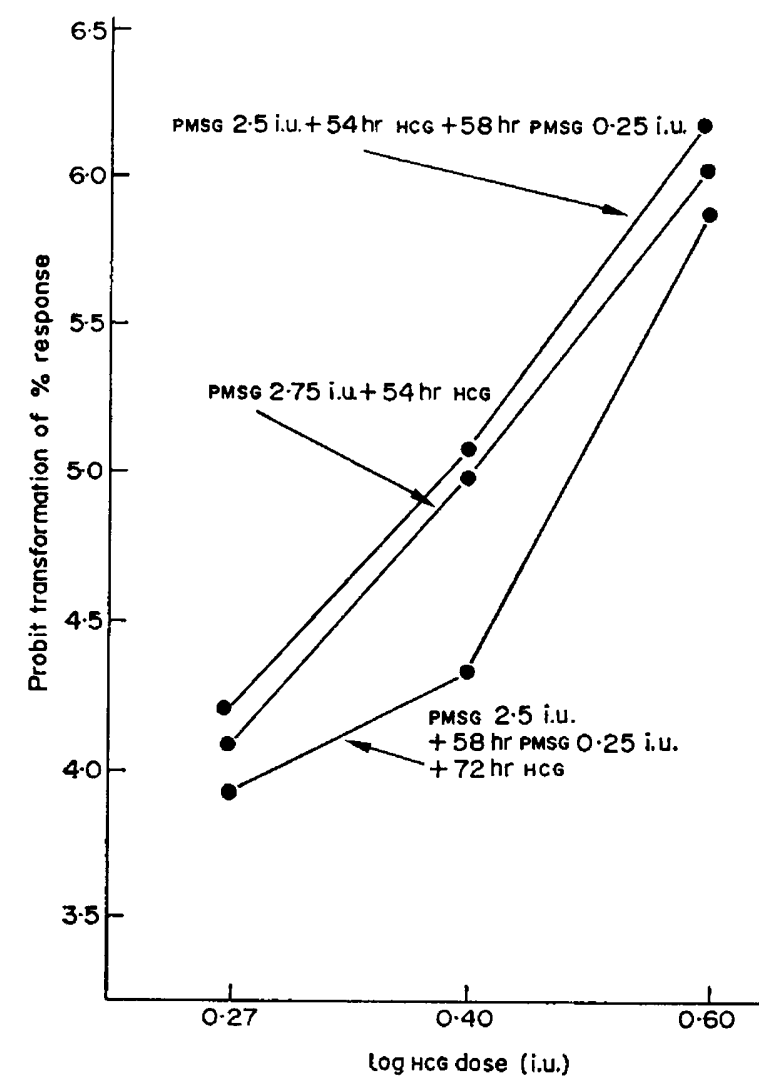

Text-Fig. 1. Log dose-response lines for the induction of ovulation in immature mice by HCG with or without a small amount of supplementary PMSG.

54-hr HCG injection with fiducial limits $(P=0.95)$ of 0.68 to 1.09 . Between the 54-hr HCG-injected groups, the potency for the group without (relative to the group with) supplementary PMSG was calculated as 0.97 with fiducial limits $(P=0.95)$ of 0.73 to 1.28 , without significant departure from linearity or parallelism.

These results indicate that the supplementary injection of a small amount of PMSG $58 \mathrm{hr}$ after pretreatment with PMSG maintained mature follicles in a state 
capable of ovulation for $72 \mathrm{hr}$ after the pretreatment, although the response to ovulating HCG showed only a slight but non-significant decrease.

\section{DISCUSSION}

When circulating PMSG was neutralized with APs during the last $6 \mathrm{hr}$ before HCG injection (60 hr after PMSG), there was a significant decrease in the percentage of animals ovulating as compared with that of the corresponding control group in which HCG and APS were given simultaneously $54 \mathrm{hr}$ after PMSG (Table 3 , Group IV-b). Perhaps, due to the deficiency of circulating PMSG during the last $6 \mathrm{hr}$, mature follicles may begin to degenerate and lose their ability to ovulate. Talbert, Meyer \& McShan (195I) reported that the maturing follicles of the rat lose their ability to ovulate by 8 to $12 \mathrm{hr}$ following hypophysectomy at the pro-oestrous stage. Eto \& Imamichi (1955) also observed that in dioestrous rats, follicles lost their ability to ovulate $10 \mathrm{hr}$ after hypophysectomy. In the present experiment using intact immature mice, complete inhibition of ovulation was observed in the group given APs $24 \mathrm{hr}$ before HCG but not in the group given APS $12 \mathrm{hr}$ before HCG. These differences may be due to the presence of endogenous circulating gonadotrophins in immature mice. Sasamoto (1962) reported that the half-life of PMSG in mice is $6 \mathrm{hr}$. The blood level of PMSG $24 \mathrm{hr}$ after administration was the same whether it was injected intravenously or subcutaneously $(12.5 \%$ of the initial level following the same amount of an intravenous injection). Therefore, only a small amount of PMSG is present in the circulating blood 54 to $60 \mathrm{hr}$ after PMSG treatment and that small amount may be responsible for the maintenance of the follicles.

When HCG injection was delayed until $72 \mathrm{hr}$ after pretreatment with PMSG, ovulation did not occur regularly (Table 4, Group I-b). Imai et al. (1965) observed that the follicles of immature mice began to show pycnosis of the granulosa cells $72 \mathrm{hr}$ after pretreatment with 2.5 i.u. PMSG. In normal cyclic female rats, however, mature follicles were still capable of ovulation when ovulating hormone release was inhibited on 2 successive days (Everett \& Sawyer, 1950), but showed atresia following inhibition on 3 successive days. These results indicate that the ovulating capacity of mature follicles can be maintained for $48 \mathrm{hr}$. Freeman, Butcher \& Fugo (1970) observed that even if ovulating hormone release was inhibited, follicular size was increasing on the day of pro-oestrus. A small amount of circulating gonadotrophin may be responsible for follicular growth and maintenance.

When a supplementary dose of $0 \cdot 25$ i.u. PMSG was injected $58 \mathrm{hr}$ after pretreatment, ovulation was regularly induced by injecting HCG $72 \mathrm{hr}$ after PMSG pretreatment (Table 4, Group II-b). The small amount of supplementary PMSG given at $58 \mathrm{hr}$ may act upon mature follicles to prevent the degenerative changes which otherwise occurred in these follicles and to maintain the ability to ovulate until $72 \mathrm{hr}$ after PMSG pretreatment. By giving a second injection of PMSG, the blood level of the hormone is slightly increased above the threshold required for the maintenance of mature follicles. When immature mice were pretreated with 10 i.u. PMSG, the ovulatory response to HGG at $72 \mathrm{hr}$ was observed regularly, although some of the follicles showed premature luteinization 
and the sensitivity to ovulating HCG was decreased (Imai, Nishino \& Sasamoto, 1960; Sasamoto \& Murakami, 1961a). Sufficient PMSG for the development and maintenance of the follicles may be present in the circulating blood $72 \mathrm{hr}$ after pretreatment with excess PMSG.

An unsolved problem raised by the present study is the identity of the ova ovulated by HCG injection at $72 \mathrm{hr}$ in the group given supplementary PMSG with those ovulated by HGG $54 \mathrm{hr}$ after pretreatment with PMSG. It is believed that, in the present experiments using immature mice, induction of ovulation by HCG at $72 \mathrm{hr}$ in the group given supplementary PMSG corresponds to the mature follicles $54 \mathrm{hr}$ after pretreatment with PMSG.

The optimum amount of PMSG required for the development of secondary follicles into mature follicles was estimated as 2.5 to 3 i.u. (Sasamoto \& Murakami, 1961a; Imai et al., 1965). The ovulatory capacity of the mature follicles was maintained by administration of 0.25 i.u. PMSG, a tenth of the dose required for follicular development.

Ladman (1964), using the method of HCG-induced ovulation after PMSG treatment, reported that the biological life of 2 i.u. PMSG is 6 days in immature mice. In these experiments, 2 i.u. HGG produced maximal ovulation 24 to $30 \mathrm{hr}$ after 2 i.u. PMSG. Only a small decrease was observed in the percentage ovulation rate induced by HGG up to $60 \mathrm{hr}$ after PMSG but the rate decreased significantly when HCG injection was delayed $100 \mathrm{hr}$. In the present experiments, maximal ovulation was obtained 54 to $60 \mathrm{hr}$ after PMSG. The ovaries of immature mice just before PMSG treatment contained a large number of secondary follicles and a few small vesicular follicles. Medium and large vesicular follicles were seldom observed (Imai et al., 1960). In these two experiments, the difference in the optimal interval between PMSG and HGG injections may be due to the different stages of follicular development in the ovaries of mice at the time of PMSG administration. From the follicular development and maintenance in immature mice by the optimal amount of PMSG, it is concluded that the biological active life of PMSG is 54 to $60 \mathrm{hr}$. After that, the amount of circulating PMSG decreases below the threshold level necessary for the functional maintenance of mature follicles, although a small amount of endogenous gonadotrophin may exist.

Supplementary administration of 0.25 i.u. PMSG $58 \mathrm{hr}$ after pretreatment had little influence on the induction of ovulation by HGG $54 \mathrm{hr}$ after PMSG pretreatment (Table 4, Group II-a versus Group I-a). Pregnant mares' serum gonadotrophin can induce ovulation when given in a dose of more than 1 i.u. subcutaneously or 0.45 i.u. intravenously (Sasamoto, 1962). In the present experiments, supplementary PMSG was given $4 \mathrm{hr}$ after the ovulating HCG, when mature follicles had probably been destined to ovulate (Sasamoto, 1969, 1970). The other follicles which did not ovulate following injection of HCG were assumed to be too small to respond to the $0 \cdot 25$ i.u. PMSG supplement. When HCG and PMSG, as ovulating hormones, were injected simultaneously, no augmenting effect on the induction of ovulation was observed by Wells, Khosla \& Brown (1964).

\section{ACKNOWLEDGMENTS}

The authors wish to thank Dr L. E. Barnes, Altech Laboratories, Madison, Wisconsin, for his revision in the preparation of the manuscript. 
Thanks are also due to the laboratory of Tomoda Pharmaceutical Co. (Tokyo) for supplies of PMSG and HGG.

\section{REFERENCES}

Burdick, H. O. \& WhrTney, R. (1941) Ovulation induced in mice by single injection of follutein or untreated human pregnancy urine. Am. F. Physiol. 132, 405.

Eто, T. \& Iмamichr, T. (1955) On the induction of ovulation in mice and rats by the single subcutaneous injection of human chorionic gonadotrophin. Endocr. jap. 2, 149.

Everett, J. W. \& SAWYer, C. H. (1950) A 24-hr periodicity in the "LH-release apparatus" of female rats disclosed by barbiturate sedation. Endocrinology, 47, 198.

Finney, D. J. (1964) Statistical method in biological assay, 2nd edn, p. 468. Charles Griffin, London.

Freeman, M. E., Butcher, R. L. \& Fugo, N. W. (1970) Alteration of oocytes and follicles by delayed ovulation. Biol. Reprod. 2, 209.

Imai, M., Nishino, Y. \& Sasamoto, S. (1960) Histological studies on the mouse ovary treated with PMS and HGG (I). J. vet. Med. No. 292, 18 [in Japanese].

Imai, M., Sasamoto, S. \& SuzuKI, T. (1965) Histological studies on the mouse ovary treated with PMS and HCG (II). Jap. 7. Anim. Reprod. 10, 114 [in Japanese].

LADMAN, A. J. (1964) Determination of length of biological life of pregnant mare's serum gonadotropin in immature mice. Proc. Soc. exp. Biol. Med. 117, 498.

Rowlands, I. W. (1944) The production of ovulation in the immature rat. F. Endocr. 3, 384.

Runner, M. N. \& Palm, J. E. (1953) Transplantation and survival of unfertilized ova of the mouse in relation to postovulatory age. F. exp. Zool. 124, 303.

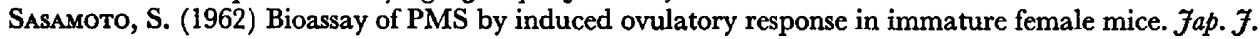
vet. Sci. 24, 451 [in Japanese].

SASAMOTO, S. (1969) Inhibition of HCG-induced ovulation by anti-HCG serum in immature mice pretreated with PMSG. 7. Reprod. Fert. 20, 271.

Sasamoto, S. (1970) Studies on the induction of ovulation in mice by gonadotrophins. Bull. Fac. Agric., Tokyo Univ. Agric. Technol. No. 13, 1 [in Japanese].

SASAmoto, S. \& MURAKAMI, K. (1961a) Bioassay of gonadotrophins by induced ovulatory response in immature mice. I. On the dosage of priming PMs for the aid of induction of ovulation. $\mathcal{F} a p . \mathcal{F}$. Anim. Reprod. 6, 163 [in Japanese].

Sasamoto, S. \& Murakami, K. (1961b) Bioassay of gonadotrophins by induced ovulatory response in immature mice. II. On the optimum interval between PMS-priming and HCG injection. $\mathcal{F} a p . \mathcal{F}$. Anim. Reprod. 7, 17 [in Japanese].

TALbert, G. B., Meyer, R. K. \& MaShan, W. H. (1951) Effect of hypophysectomy at the beginning of proestrus on maturing follicles in the ovary of the rat. Endocrinology, 49, 687.

Wells, M., KhOSLA, T. \& BROWN, P. S. (1964) An investigation of the assay of gonadotrophin by the induction of ovulation in immature mice. F. Endocr. 29, 311.

WiLson, E. D. \& ZARROW, M. X. (1962) Comparison of superovulation in the immature mouse and rat. J. Reprod. Fert. 3, 148.

Zarrow, M. X., Galdwell, A. L., Hafez, E. S. E. \& Pincus, G. (1958) Superovulation in the immature rat as a possible assay for LH and HCG. Endocrinology, 63, 748. 